\title{
SPLINE MODELS OF CONTEMPORARY, 2030, 2060 AND 2090 CLIMATES FOR MICHOACÁN STATE, MÉXICO. IMPACTS ON THE VEGETATION
}

\author{
MODELOS “SPLINE” DE CLIMAS CONTEMPORÁNEO, 2030, 2060 Y 2090 PARA MICHOACÁN, \\ MÉXICO. IMPACTOS EN LA VEGETACIÓN
}

\author{
Cuauhtémoc Sáenz-Romero ${ }^{1 *}$, Gerald E. Rehfeldt ${ }^{2}$, Nicholas L. Crookston ${ }^{2}$, Pierre Duval ${ }^{3}$ and Jean Beaulieu ${ }^{4}$
}

\begin{abstract}
${ }^{1}$ Instituto de Investigaciones Agropecuarias y Forestales, Universidad Michoacana de San Nicolás de Hidalgo (IIAF-UMSNH). Km 95 Carr. Morelia-Zinapécuaro. Tarímbaro, Michoacán. 58880, México. Phone: + (52)(443) 3340475 ext. 118, Fax ext. 200. ${ }^{2}$ Forestry Sciences Laboratory, Rocky Mountain Research Station, USDA, Forest Service. 1221 S. Main, Moscow, Idaho, 83843, USA. ${ }^{3}$ Center de Foresterie des Laurentides, Service Canadien des Forets, Ressources Naturelles Canada, 1055 rue du P.E.P.S., 10380 Succ. Sainte-Foy, Québec QC G1V4C7, Canada. ${ }^{4}$ Center Canadien sur la Fiebre de Bois, Service Canadien des Forest, Ressources Naturelles Canada. 1055 rue du P.E.P.S., 10380 Succ Sainte-Foy, Québec QC G1V 4C7, Canada.
\end{abstract}

${ }^{*}$ Corresponding author (csaenzromero@gmail.com)

\section{SUMMARY}

Climate data from 149 weather stations of Michoacán State, at Western México, were extracted from a spline climate model developed for México's contemporary climate (1961-1990), and for climate projected for the decades centered in years 2030, 2060 and 2090. The model was constructed using outputs from three general circulation models (GCMs: Canadian, Hadley and Geophysical Fluid Dynamics) from two emission scenarios (A "pessimistic" and B "optimistic"). Mean annual temperature (MAT), mean annual precipitation (MAP), annual degree days $>5^{\circ} \mathrm{C}$ (DD5), and annual aridity index (DD5 $\left.5^{0.5} / \mathrm{MAP}\right)$ were mapped for Michoacán at an $1 \mathrm{~km}^{2}$ scale, and means were estimated averaging all weather stations. The state average in GCMs and emission scenarios point out that mean annual temperature would increase 1.4 ${ }^{\circ} \mathrm{C}$ by year $2030,2.2{ }^{\circ} \mathrm{C}$ by year 2060 and $3.6^{\circ} \mathrm{C}$ by year 2090 ; whereas annual precipitation would decrease $5.6 \%$ by year $2030,5.9 \%$ by year 2060 and $7.8 \%$ by year 2090 . Climate models can be used for inferring plant-climate relationships and for developing programs to counteract global warming effects. Climate variables were estimated also at Pinus hartwegii and Pinus pseudostrobus growth locations, at Pico de Tancítaro in Central Western Michoacán and Nuevo San Juan Parangaricutiro (near Tancítaro), respectively. According to the annual aridity index values estimated for such locations, it is necessary to conduct assisted migration to match current genotypes to projected climates. This translates into an altitudinal shift of 400 to $\mathbf{4 5 0} \mathrm{m}$ higher to match 2030 climates predicted by Canadian Model scenario A2, and 600 to $800 \mathrm{~m}$ to match 2060 climates.

Index words: Pinus hartwegii, Pinus pseudostrobus, assisted migration, climate change, emission scenarios, Michoacán, thin plate smoothing splines.

\section{RESUMEN}

Datos climáticos de 149 estaciones climáticas del Estado de Michoacán, al oeste de México, fueron extraídos de un modelo climático "spline" desarrollado para México para el clima contemporáneo (19611990) y para proyecciones de clima para décadas centradas en los años 2030, 2060 y 2090, con base en salidas de tres modelos de circulación global (GCM: Canadian, Hadley y Geophysical Fluid Dynamics), de dos escenarios de emisiones (A "pesimista" y B "optimista"). Temperatura media anual (MAT), precipitación anual promedio (MAP), grados día anuales $>5{ }^{\circ} \mathrm{C}$ (DD5) y un índice de aridez (DD5 ${ }^{0.5} / \mathrm{MAP}$ ) fueron mapeados para Michoacán a una escala de $1 \mathrm{~km}^{2}$, y se estimaron medi- as de todas las estaciones. Con base en promedios para el estado y entre GCM y escenarios de emisiones, se estima que la temperatura promedio anual se incrementaría en $1.4^{\circ} \mathrm{C}$ para el año 2030, en $2.2^{\circ} \mathrm{C}$ para el año 2060 , y en $3.6^{\circ} \mathrm{C}$ para el año 2090; la precipitación anual decrecerá en $5.6 \%$ para el año 2030, $5.9 \%$ para el año 2060 y $7.8 \%$ para el año 2090. Los modelos climáticos pueden ser usados para inferir relaciones planta-clima y para desarrollar programas que aminoren los efectos del calentamiento global. Las variables climáticas fueron estimadas para localidades donde actualmente crecen poblaciones de Pinus hartwegii en Pico de Tancítaro, al centro-oeste de Michoacán, y Pinus pseudostrobus en Nuevo San Juan Parangaricutiro (cerca de Tancítaro). Con valores del índice de aridez estimados para esas localidades, se concluye que es necesario realizar migración asistida para acoplar genotipos actuales con climas predichos, mediante un ascenso altitudinal de 400 a $450 \mathrm{~m}$ para acoplarse a los climas predichos para 2030 por el modelo Canadiense escenario A2, y de 600 a $800 \mathrm{~m}$ para acoplarse a climas del 2060.

Palabras clave: Pinus hartwegii, Pinus pseudostrobus, migración asistida, cambio climático, escenarios de emisiones, Michoacán, modelos "spline" suavizados de capas delgadas.

\section{INTRODUCTION}

The state of Michoacán is located in Western México. It is the highest nationwide producer of pine resin (35 thousand tons per year), the third in timber production (with about 1 million $\mathrm{m}^{3}$ /year, only after the two largest forested states of México: Chihuahua and Durango), and the fifth in biodiversity (COFOM, 2001; Villaseñor-Gómez, 2005). The state is especially rich in tree species: 37 species of genus Bursera in the tropical dry forest, 35 of genus Quercus, and 15 of genus Pinus in the oak and coniferous forest (Cué-Bär et al., 2006). Pine species account for approximately $80 \%$ of the legal production of timber (COFOM, 2001).

Despite the large biological richness and economic importance of forest tree species in Michoacán, there are official estimations of deforestation of about 30000 to 40000 
ha/year due to land use change from forest to agriculture and grazing, to forest fires (intentional and natural), and to illegal cutting (COFOM, 2001; Sáenz-Romero, 2005).

Climate change complicates the status of forest resources. It is expected that by the end of the century, entire ecosystems will be decoupled of their natural distribution climate, and numerous tree species and populations will disappear, unless they adapt or migrate (Rehfeldt et al., 1999; Hughes, 2000; Rehfeldt et al., 2001; Tchebakova et al., 2005; Rehfeldt et al., 2006; Aitken et al., 2008). Climate change expectations in México include a drastic 7 to $48 \%$ reduction of suitable habitats for oaks and 0.2 to $64 \%$ for pines by 2050 , depending of the scenario used for estimating effects (Gomez-Mendoza and Arriaga, 2007), and the likely extinction of the rare endemic Picea species, already endangered in México (Ledig et al., 2010).

Considering climate as the primary factor controlling the distribution of plants (Brown and Gibson, 1983; Tukanen, 1980; Woodward, 1987), the understanding of plant-climate relationships is essential for designing comprehensive programs for management and conservation of forest tree species. These programs should aim at impact mitigation of ongoing climatic change. For example, it is necessary to redraw existing natural protected areas boundaries for biological conservation (Téllez-Valdes and Dávila-Aranda, 2003), to assist migration of plant populations northwards or higher elevations (Hughes, 2000; Tchebakova et al., 2005; Aitken et al., 2008), and to increase tree plantation genetic diversity to facilitate adaptive responses to climatic change (Ledig and Kitzmiller, 1992; St. Clair and Howe, 2007). All this actions require access to contemporary and future climate estimates (Tchebakova et al., 2005).

Reforestation for ecological restoration and commercial plantations conducted with local seed sources might not be a good option any longer. The traditional guidelines for matching genotypes to naturally adapted climates require adjustments to consider that current climate, in any given geographical area, will change in the near future (Hughes, 2000; Rehfeldt et al., 2006; Sáenz-Romero et al., 2006; Gomez-Mendoza and Arriaga, 2007; St Clair and Howe, 2007; Aitken et al., 2008).

In this paper, our objectives were to estimate averages of temperature, precipitation and aridity for the state of Michoacán, México, for contemporary climate conditions and for six projected climate change model-scenarios, for decades centered in the years 2030, 2060 and 2090. We also discuss implications for forest genetic resources. Data estimations were extracted from a nationwide project presented elsewhere (Sáenz-Romero et al., 2010), in which thin plate smoothing splines were used (Hutchinson, 2004).

\section{METHODS}

\section{Contemporary climates}

Monthly averages, normalized for the 1961-1990 period (contemporary climate) from 149 weather stations in $\mathrm{Mi}-$ choacán state (Figure 1), of total precipitation, maximum, minimum and mean temperatures were taken from a database that included monthly means from 4000 stations in México, Southern USA, Guatemala, Belize and Cuba (Sáenz-Romero et al., 2010). The 149 weather stations had complete data for all monthly means for the four climate variables. Monthly estimates were converted into 19 variables of relevance to plants (see Tukanen, 1980; Rehfeldt et al., 2006), according to the algorithms of Rehfeldt (2006), using a SAS program (SAS Institute, 1998).

In the results section, we will present only the four most relevant variables to illustrate climatic change and potential impacts on vegetation: mean annual temperature (MAT, ${ }^{\circ} \mathrm{C}$ ), mean annual precipitation (MAP, mm), degree-days above $5{ }^{\circ} \mathrm{C}$ (DD5), and annual aridity index (AAI = DD5 ${ }^{0.5} /$ MAP). MAT was estimated by averaging the 12 monthly temperature means (one monthly mean for each month of the year). MAP was estimated in a similar fashion, by adding the monthly precipitation. However, DD5 estimation was more complicated and included linear and nonlinear regressions calculated for given intervals of monthly mean temperatures values (see regression parameter values and Figure 3 on Rehfeldt, 2006).

Thin plate splines for México and neighboring countries were fit to normalized monthly means (using data from the 4000 stations) with the software ANUSPLIN v 4.3 (Hutchinson, 2004). This software fits smoothing parameters to latitude, longitude and altitude coordinates as independent variables of a geographic space. Fitting the spline model was conducted in three iterations, where the final surfaces were produced using 1921 knots for precipitation and 1703 for temperature. We used the module SPLINB to eliminate those monthly observations laying more than 3.6 standard deviations off the surface. In the final model, these observations were not used to produce the climate surfaces.

The goodness of fit of the model was assessed from three diagnostic statistics: the signal, root mean square error (RTMSE), and root of the generalized cross validation statistic (RTGCV). The result was adequate, considering that the signal averaged 0.26 for temperatures and 0.36 for precipitation; the standard errors for the surfaces were less than $1{ }^{\circ} \mathrm{C}$ for the monthly means of temperature and 10 $15 \%$ for precipitation. These values are estimated averages between conservative standard error estimations (generalized cross validation statistics, RTGCVs), and optimistic 
estimates (root mean square errors, RTMSEs) (Hutchinson 2004). More details to purge weather station data, normalization, fitting and assessment of the spline surfaces, are described and discussed in Sáenz-Romero et al. (2010).

Monthly estimates from the spline surfaces were converted to derived variables MAT, MAP, DD5 and AAI, for map illustration of climate diversity in Michoacán. Estimations were calculated evaluating the spline surface model for each cell of a digitized elevation model (Globe Task team, $1999)$ at $0.5 \mathrm{~min}$ into a grid (0.008333 degrees or approximately $1 \mathrm{~km}^{2}$ ), including data from states surrounding Michoacán. The derived variables were then estimated at each data point of the grid using the same algorithms than those described for the 149 weather stations. The derived variable grids were then mapped with geographical information software (Minami, 2000).

\section{Future climate}

To estimate the future climates of Michoacán State for the decades centered in the years 2030, 2060 and 2090, monthly values of precipitation and minimum, maximum and average temperatures were extracted for all weather stations. Data was updated with outputs from a combination of three general circulation models (GCMs) and two emission scenarios for each GCM: (a) Canadian Center for Climate Modeling and Analysis (CCC), using the CGCM3 (T63 resolution) model, SRES A2 and B1 scenarios; (2) Met Office, Hadley Centre (HAD), using the HadCM3 model, SRES A2 and B2 scenarios; and (3) Geophysical Fluid Dynamics Laboratory (GFD), using the CM2.1 model, SRES A2 and B1 scenarios.

The three general circulation models were selected to encompass (for North America) most of the variability among numerous available GCMs. Descriptions of the models can be found at http://www.ipcc-data.org/, and an overview of the variability among models is well illustrated by Christensen et al. (2007). Emission scenario A2 assumes high continuous emissions from a human population that keeps growing along the XXI century, with heterogeneous economic growth and technological change among different regions and countries of the world. Emission scenario B assumes a gradual reduction in emissions as rapid changes in economic structures are made toward a reduction in material intensity and introduction of clean technologies. For more details about emission scenarios families, see IPCC (2000).

The International Panel for Climatic Change (IPCC) officially claims that there are equal probabilities of occurrence associated to each emission scenarios (IPCC, 2000). However, for simplification, in this research, scenario A2 will be labeled as "pessimistic" (although, perhaps the most probable), and scenarios B as the "optimistic" (perhaps the most unlikely). Data update for weather stations was made by weighted average of the climate monthly change calculated for the GCM cell centers lying within $400 \mathrm{~km}$ of each station. The splines were then refitted for each combination of GCMs, emission scenarios and time periods to produce monthly surfaces for the four climate variables. Derived variables were then calculated as described above. We illustrate projected changes in climate by mapping the state of Michoacán as we did for contemporary climate. Other nationwide mapped projections are available at http://forest. moscowfsl.wsu.edu/climate/.

\section{Plant-climate relationships}

To illustrate the utility of the climate surfaces in forest resources management, we projected contemporary and future (year 2030) climate for populations within two species of pine inhabiting altitudinal transects in the Neovolcanic (also known as Transvolcanic) Axis of Michoacán State (see Figure 1 for geographic reference). Genetic responses of populations separated by $100 \mathrm{~m}$ of elevation have been studied previously for $P$. pseudostrobus populations from 2100 to $2800 \mathrm{~m}$ at the Nuevo San Juan Parangaricutiro region, near Pico de Tancítaro (Viveros-Viveros et al., 2005). Similar responses were collected for $P$. hartwegii populations separated by $50 \mathrm{~m}$ of elevation, from 3000 to $3600 \mathrm{~m}$ at Pico de Tancítaro (Viveros-Viveros et al., 2009). In this paper, contemporary, 2030 and 2060 values of four derived variables: MAT, MAP, DD5, and AAI (DD5 $\left.{ }^{0.5} / \mathrm{MAP}\right)$ are examined. Analyses and discussion are covered in Sáenz-Romero et al. (2010). From these estimates, altitudinal distance the populations would need to be transferred, if they were to grow in a climate similar to the one inhabited today but when such climate occurs at different altitude, was calculated. The underlying assumption is that existing populations are genetically adapted to contemporary climates (Saenz-Romero et al., 2006).

\section{RESULTS AND DISCUSSION}

\section{Projected climates}

Average data from all weather stations showed that contemporary climate of Michoacán state has a mean annual temperature of $20.3^{\circ} \mathrm{C}$ and a mean annual precipitation of $909 \mathrm{~mm}$. Average monthly distribution indicate that May is the warmest month and July, August and September are the wettest months (Figure 2).

Weather station averages, updated for the three GCM models, and combinations with the two emission scenarios, A2 and B outputs, show that projected mean annual 


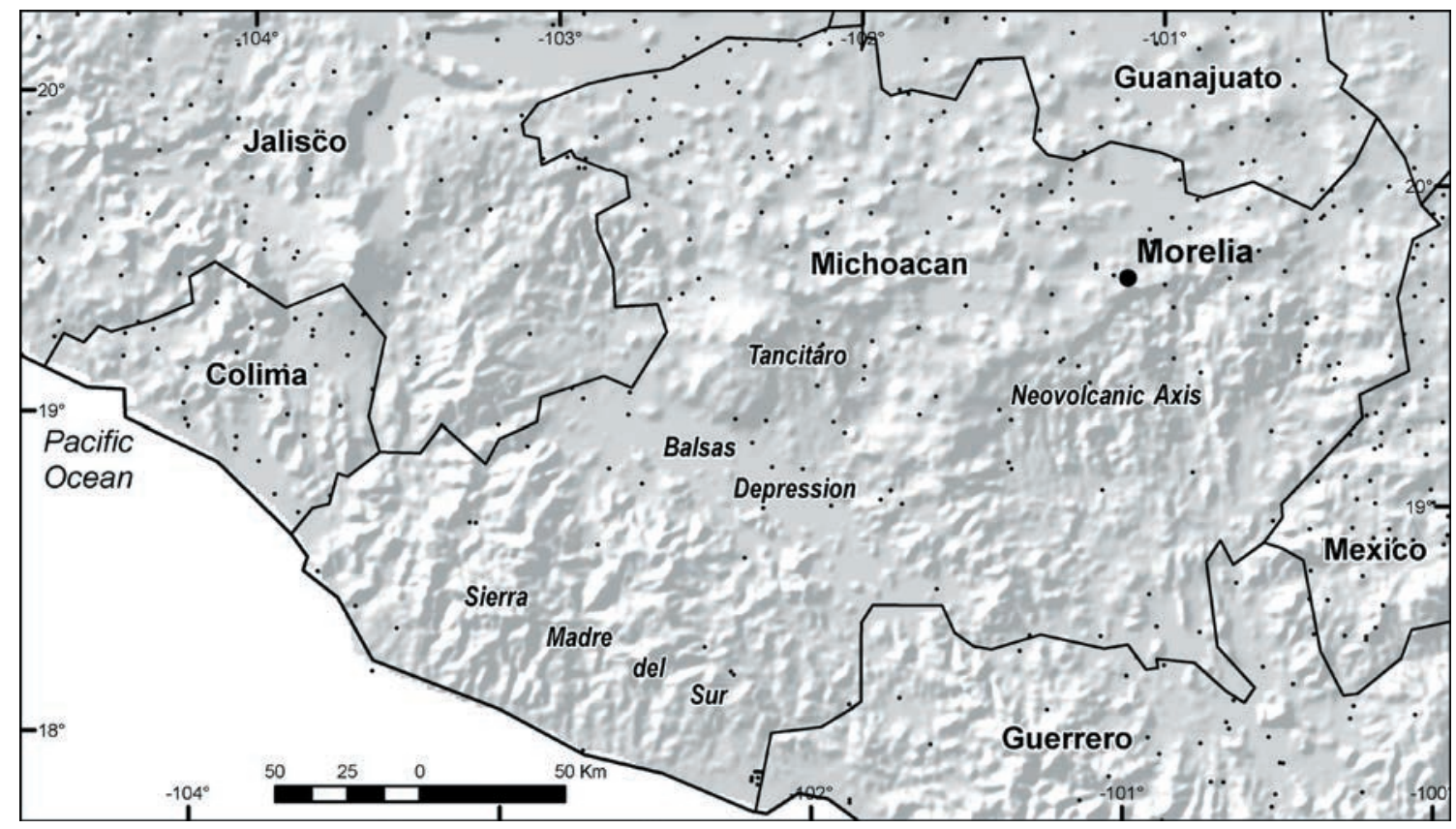

Figure 1. State borders, prominent geographical regions, and location of 149 weather stations used for the spline surfaces at Michoacán State and Western México, as referenced in text.

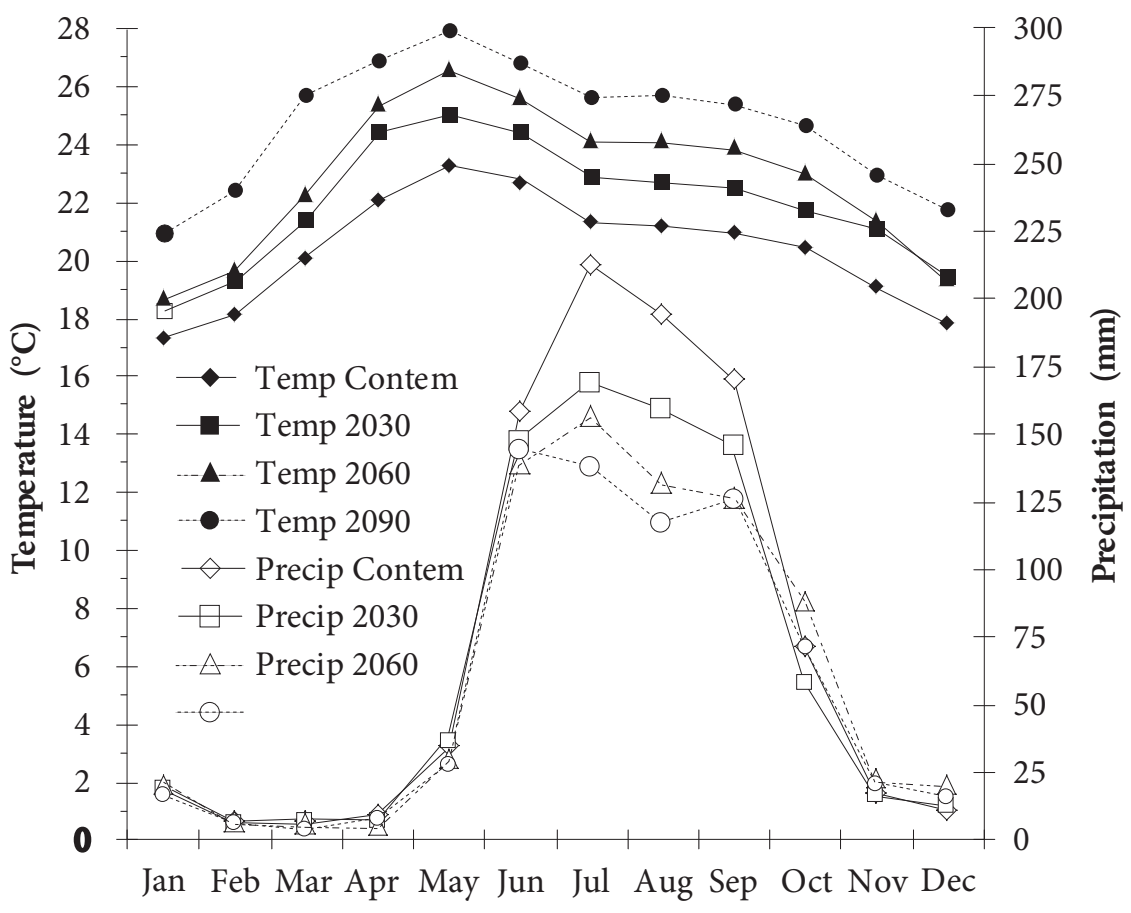

Month

Figure 2. Average monthly temperature $\left({ }^{\circ} \mathrm{C}\right)$ and precipitation $(\mathrm{mm})$ averaged at Michoacán State for contemporary, 2030, 2060 and 2090 climates. Future climate was projected based on outputs from the Canadian Center for Climate Modeling and Analysis (CCC) model scenario A2. 
temperatures (compared to contemporary climate) could increase steadily in Michoacán by $1.4{ }^{\circ} \mathrm{C}$ by the decade centered in year $2030,2.2^{\circ} \mathrm{C}$ by 2060 , and $3.6^{\circ} \mathrm{C}$ by 2090 (Figure 3).

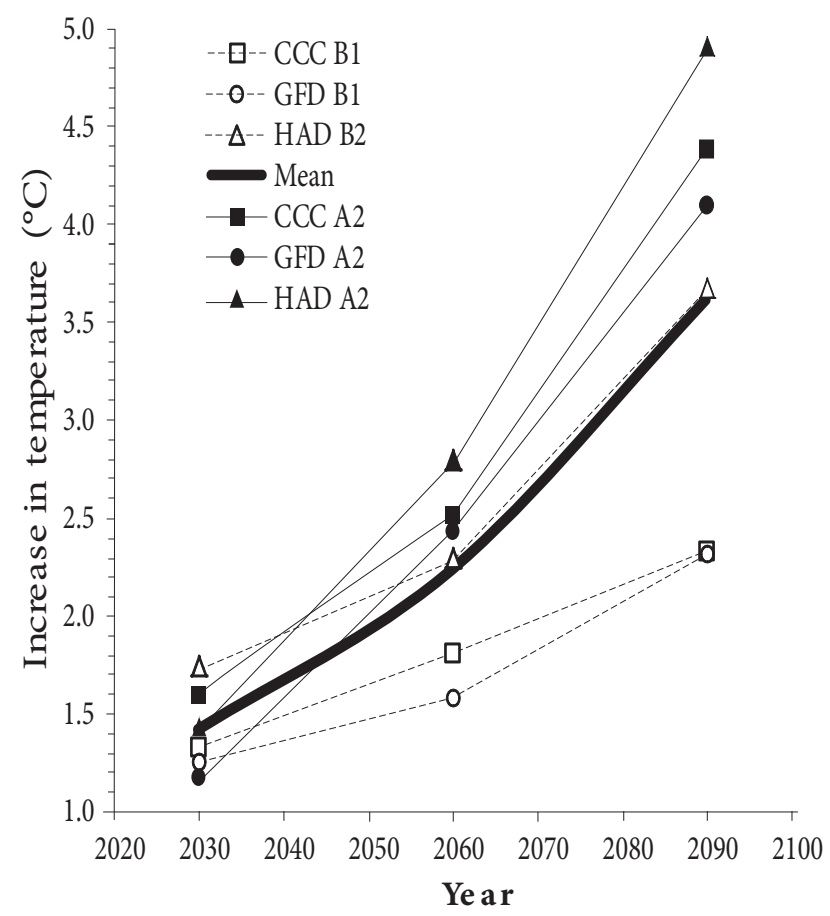

Figure 3. Average increment of mean annual temperature $\left({ }^{\circ} \mathrm{C}\right)$ in comparison to contemporary climate (1961 - 1990), from 149 weather stations at Michoacán State. Data is updated from three general circulation models and two emission scenarios: Canadian Center for Climate Modeling and Analysis (CCC, emission scenarios A2 and B1), Hadley Centre (HAD, scenarios A2 and B2) scenarios, and Geophysical Fluid Dynamics Laboratory (GFD, scenarios A2 and B1), for decades centered in years 2030, 2060 and 2090.

Projections, however, increasingly diverge among scenarios during the course of the century. For 2030, all scenarios were similar, with the largest difference $\left(0.5^{\circ} \mathrm{C}\right)$ between GCM Hadley scenario A2 $\left(1.7^{\circ} \mathrm{C}\right.$ increase) and GCM GFD scenario A2 (1.2 ${ }^{\circ} \mathrm{C}$ increase). By 2060 , particularly among emission scenarios, the differences increased, with the largest difference being $1.2{ }^{\circ} \mathrm{C}$ between Hadley scenario A2 (2.8 ${ }^{\circ} \mathrm{C}$ increase) and GFD scenario $\mathrm{B} 1\left(1.6^{\circ} \mathrm{C}\right.$ increase). By year 2090, discrepancy between emission scenarios was larger; for example, Hadley A2 predicts an increment of $4.9^{\circ} \mathrm{C}$ while GFD B1 estimates $2.3{ }^{\circ} \mathrm{C}$, a $2.6{ }^{\circ} \mathrm{C}$ difference. The large divergence among emission scenarios illustrate the enormous future impact, from now to the end of the century, in the amount of greenhouse gas emissions. The "business as usual" emission scenarios A2 would result in a catastrophic increment between 4 to $5{ }^{\circ} \mathrm{C}$. Reduction of emissions, starting today, would result, at best, in emission scenario B: a $2.3{ }^{\circ} \mathrm{C}$ increment for GCMs Canadian and
GFD. The 2090 projected increases shown in Figure 3 are similar to the averages projected for México, Southern USA (below $33^{\circ} \mathrm{LN}$ ), Guatemala, Belize and Cuba.

These temperature increments are $1.5^{\circ} \mathrm{C}$ for $2030,2.3^{\circ} \mathrm{C}$ for 2060 , and $3.7^{\circ} \mathrm{C}$ for 2090 (Sáenz-Romero et al., 2010) and are within the ranges of temperature increments of 21 global models projected for México and Central America between 2080 and 2099 (Christensen et al., 2007). However, the similarities with Sáenz-Romero et al. (2010) averages for Michoacán and México do not mean that the temperature will increase homogeneously across México.

Mapping the differences between contemporary average annual temperature and projected temperatures for the decade centered in the year 2090 using the CCC model and A2 scenario points out that although Michoacán state has values near the average temperature increments (close to $4{ }^{\circ} \mathrm{C}$, Figure 4 ), Northwestern México will have larger temperature increments. These increments could be as large as 5.5 to $6.0^{\circ} \mathrm{C}$, whereas the Northern Yucatán Peninsula will increase temperature the lowest, between 2.3 and $3.0^{\circ} \mathrm{C}$ (Figure 4), probably due to a buffering effect from the Golf stream. The substantial temperature increment predicted in Northwestern México, unfortunately, has been already registered. Differences are statistically significant when climate data from the 1970 to 2004 period are compared to the 1940 to 1969 period (Pavia et al. 2009).

Annual precipitations averaged across GCMs and emission scenarios show that the predicted annual precipitation (Figure 5) will decrease by $5.6 \%$ by 2030, $5.9 \%$ by 2060 , and $7.8 \%$ by 2090. Projections for 2030 varied between 2.0 $\%$ decreases for GFD scenario B1, to $14.2 \%$ for CCC A2; projections for 2060 varied between $0.4 \%$ decreases for HAD scenario B1, to $17.3 \%$ for CCC A2. By 2090, projected scenarios predict a precipitation decrease between 0.1 $\%$ for HAD A2 to $24.2 \%$ for CCC A2. The general trend of annual precipitation reduction is similar to Mexican averages and surrounding countries (Sáenz-Romero et al., 2010). These averages are also within the range of values predicted by Christensen et al. (2007), who predicted reductions from 21 global models by the end of the century ranging from $9 \%$ to $48 \%$ for México and Central America between 2080 and 2099.

\section{Mapped climates}

Climate variability in Michoacán state is illustrated by mapping predicted mean annual temperature, mean annual precipitation, and annual aridity index of the contemporary period and, only for the Canadian model A2 scenario, for the decades centered in the years 2030, 2060 and 2090 (Figures 6, 7 and 8). As expected, geographic patterns in mean 


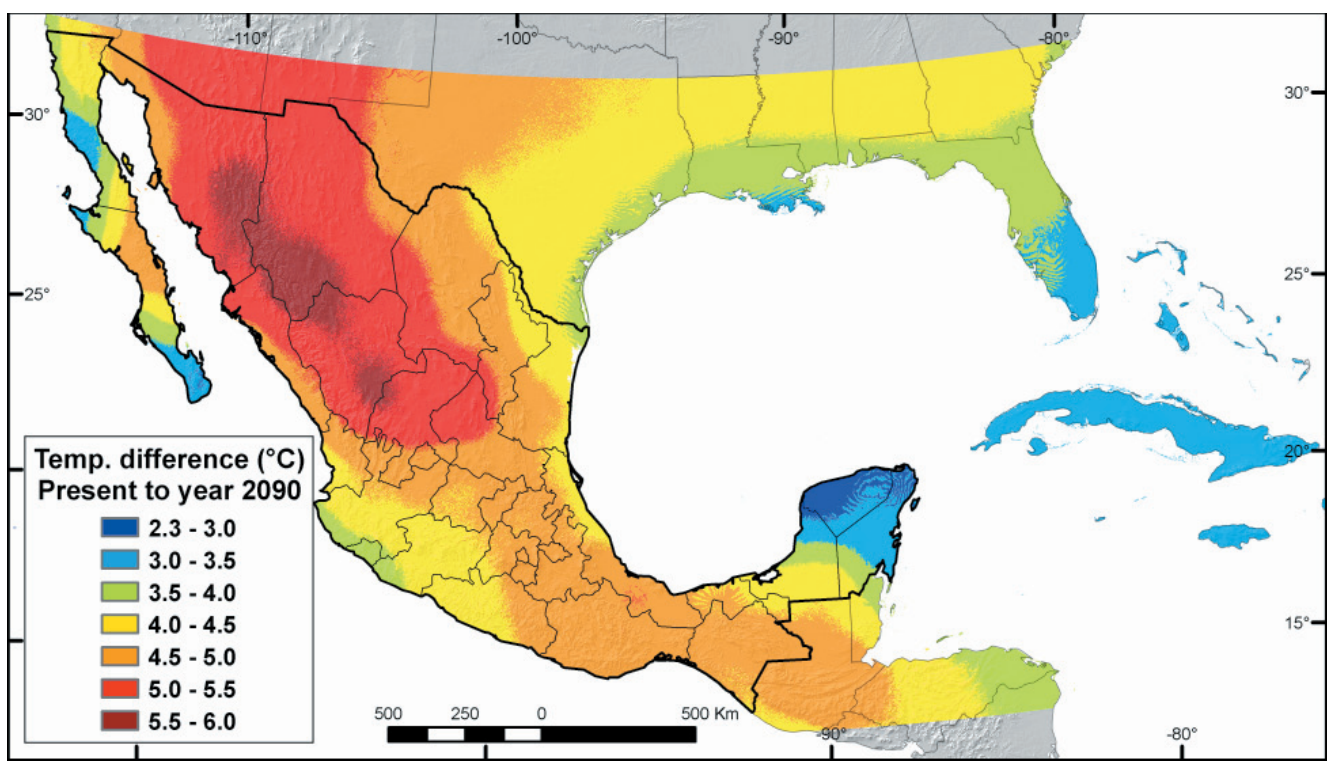

Figure 4. Differences between contemporary (1961-1990) average annual temperature and projected temperatures for year 2090, using CCC model and A2 scenario for México and surrounding regions (Southern USA below $33^{\circ} \mathrm{N}$, Guatemala, Belize, northern Honduras and Cuba).

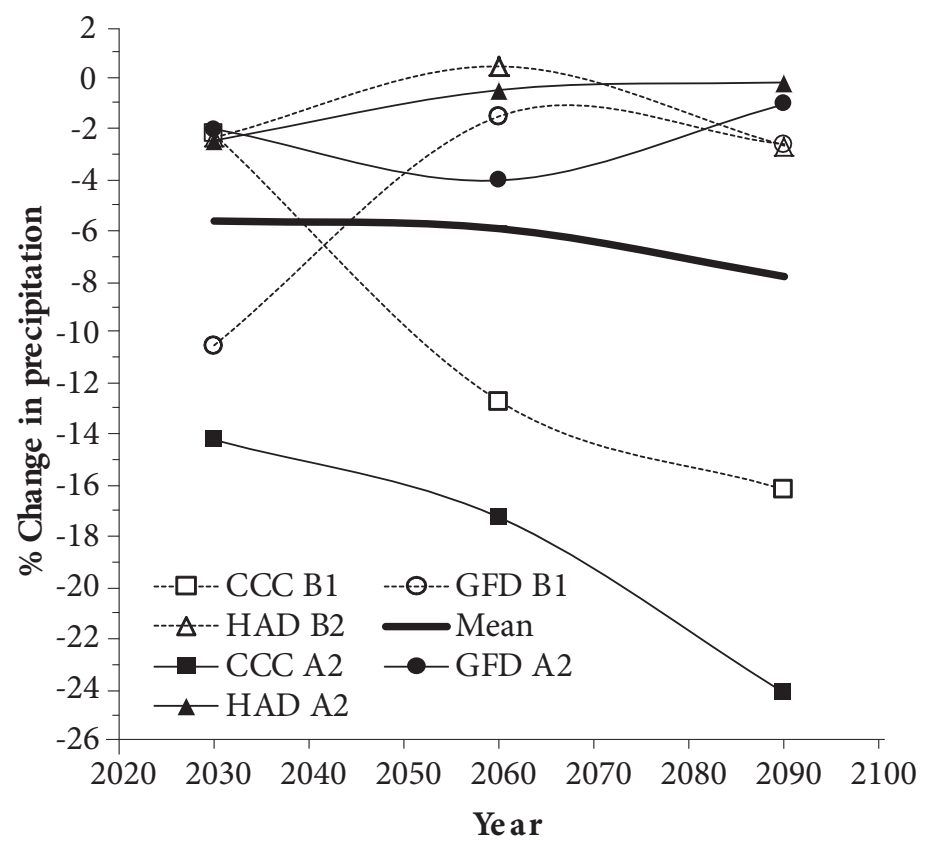

Figure 5. Mean changes in annual precipitation (\%) for the decades centered in years 2030, 2060 and 2090 for Michoacán State, in comparison to contemporary climate (1961-1990), using output from the Canadian Center for Climate Modeling and Analysis (CCC, emission scenarios A2 and B1), Hadley Centre (HAD, scenarios A2 and B2) scenarios, and Geophysical Fluid Dynamics Laboratory (GFD, scenarios A2 and B1). 
annual temperature reflect altitudinal differences between the mountain systems and the lowlands. In the contemporary climate, the coolest regions $\left(<14{ }^{\circ} \mathrm{C}\right.$, intense blue in Figure 6a) are concentrated in the West - East transect along the Neovolcanic Axis and in small mountain peaks along the Sierra Madre del Sur, a southern extension of the Sierra Madre Occidental.

The highest and coldest places are Pico de Tancítaro (Central - Western Michoacán, see Figure 1 for reference) and the North - Eastern border between Michoacán State and the State of México. Right on this border, the Biosphere Reserve for the overwintering of the Monarch Butterfly is located; reserve cores in the area contain Abies religiosa stands. Areas with temperatures greater than $25{ }^{\circ} \mathrm{C}$ occur along the interior lowlands known as Balsas Depression (Figures 1 and 6a, orange colors). Because the means of annual, maximum, and minimum temperatures and degree days with temperatures greater than $5{ }^{\circ} \mathrm{C}$ are correlated, their geographic patterns are all similar to those in Figure $6 a$.

The temperature projections for 2030, 2060 and 2090, according to CCC model and emission scenario A2, show that areas with the coolest climates $\left(<14{ }^{\circ} \mathrm{C}\right)$ should largely disappear gradually, being restricted only to the highest mountains of the Neovolcanic Axis (dark blue, Figure 6b, $c$ and $d)$.

In addition, the Balsas Depression region will turn very warm, with greater than $31{ }^{\circ} \mathrm{C}$ mean annual temperatures (darkest red shades, Figure 6d).

Highly variable contemporary precipitation are caused by a combination of altitudinal effects, differential impacts of arid westerly air masses from the Pacific Ocean, moist monsoonal flows from the Gulf of México, and rain shadow effects of mountain ranges. In the Balsas Depression, and in Michoacán State's northern border, for example, annual precipitation is between 600 to $800 \mathrm{~mm}$ (light brown color on Figure 7a). 1400 to $1600 \mathrm{~mm}$ are estimated at higher altitudes on mountains of the Neovolcanic Axis and the Sierra Madre del Sur (intense blue colors on Figure 7a). Climate change predicted by the A2 scenario of CCC model for decades 2030, 2060 and 2090, however, is expected to progressively reduce the amount of area receiving more than 1400 $\mathrm{mm}$ of rain (intense blue tones on Figures $7 \mathrm{~b}, \mathrm{c}$ and $\mathrm{d}$ ). This behavior will expand the arid and semiarid regions receiving less than $600 \mathrm{~mm}$ (dark and medium brown tones on Figures $7 b, c$ and d) in the Balsas Depression and northern Michoacán State region.

The annual aridity index (ratio of square root of degree days $>5{ }^{\circ} \mathrm{C}$ and precipitation) expresses a temperature inte- raction with precipitation that better illustrates the climate variability in Michoacán State than either component separately (Figure 8). By reflecting the amount of growing season heat received for each millimeter of annual precipitation, this ratio represents the potential for developing moisture stresses in the vegetation. In the contemporary climate (Figure 8a), lowest index values (cold and humid climate) are associated with coniferous forests located at the higher mountains of the Neovolcanic Axis (intense blue colors at Figure 8a), while the highest index values (warm and dry climate) occur in the tropical dry forest (tropical deciduous forest) and scrub semiarid Balsas Depression (dark yellow and light brown colors in Figure 8a). This map is strikingly similar to other vegetation maps of Michoacán (Rzedowskii, 1978; Cué-Bär et al., 2006).

However, according to the A2 scenario of CCC, the semiarid region of the Balsas Depression (brown tones of Figures $8 \mathrm{~b}, \mathrm{c}$ and d) will expand toward both the Northwest and Southeast, while the dry region at the northern border of the state will expand to the South. At the same time, the temperate regions of the high mountains of the Neovolcanic Axis will be warmer and dryer (blue tones disappear progressively on Figures 8b, $c$ and d).

Combinations of the other two GCMs (Hadley and GFD) with emission scenarios $\mathrm{A} 2$ and $\mathrm{B}$ show the same trends than the mapped Canadian model emission scenario A2. However, aridity increases with time less pronouncedly since GCMs Hadley and GFD predict a reduction in precipitation less severe than the Canadian model. All predicted scenarios show decreased precipitation, with large variation among GCMs, and a temperature increase with larger variations among emission scenarios. The result of these variations is that the balance between temperature and precipitation, one of the largest governing factors to vegetation distribution, follows the same trend but at different rate in time. That is, the same ratio of temperature and precipitation is reached at different times. For example, Canadian model scenario A2 reaches higher aridity index values (compared to contemporary values) earlier than values predicted by the GFD model scenario B1. This means that vegetation will receive the negative impact of the climate change later, only if the more optimistic scenarios occur instead of the more pessimistic ones. The maps of Figures 6, 7 and 8 and many additional maps are available at http:// forest.moscowfsl.wsu.edu/climate/.

\section{Applications in plant-climate relationships}

Projected impacts of climate-change on the vegetation commonly show that the current climate in local populations, species, and ecosystems, will shift toward the north 


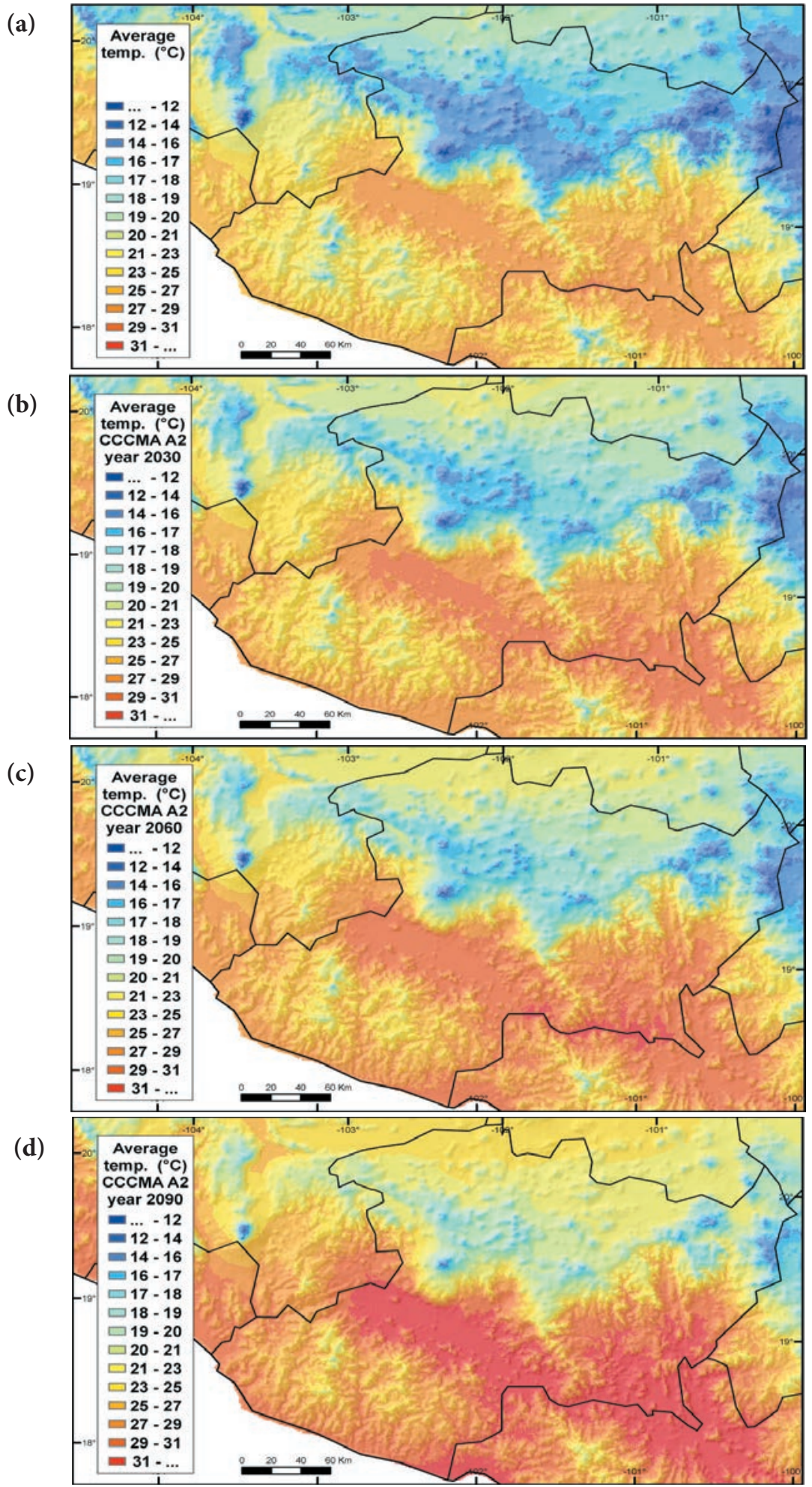

Figure 6. Mapped mean annual temperature predictions $\left({ }^{\circ} \mathrm{C}\right)$ for Michoacán state for digitized elevations on a 0.5 min $($ about $1 \mathrm{~km}$ ) grid, for contemporary (a), decades centered in the year 2030 (b), 2060 (c) and 2090 (d) climates, using output from the Canadian Center for Climate Modeling and Analysis model scenario A2. 
(a)

(b)

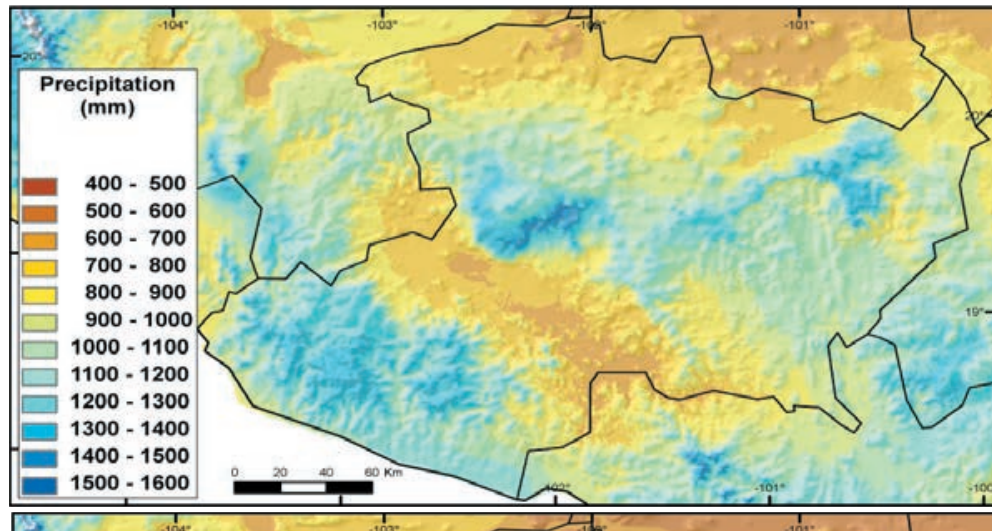

(c)

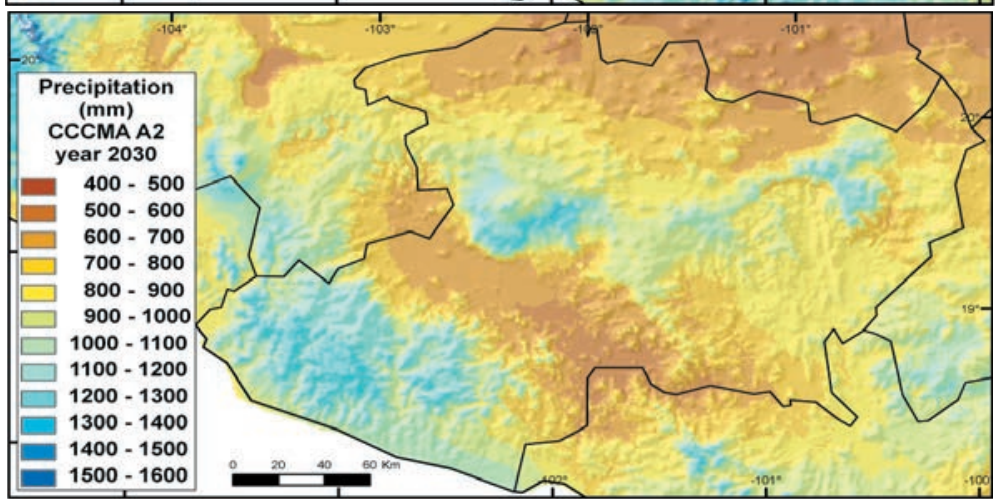

(d)
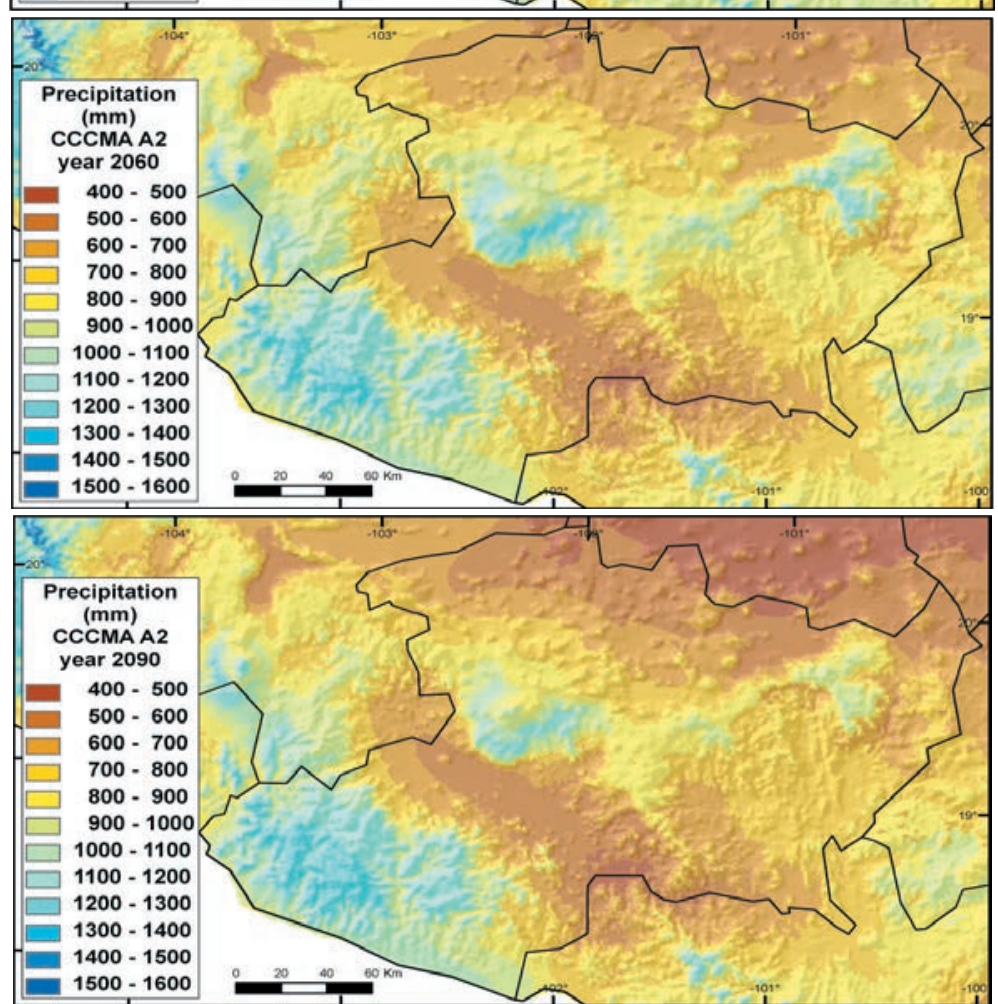

Figure 7. Mapped predictions for mean annual precipitation $(\mathrm{mm})$, for contemporary (a), decades centered in the year 2030 (b), 2060 (c) and 2090 (d) climates, using output from the Canadian Center for Climate Modeling and Analysis model, scenario A2. 
(a)

(b)
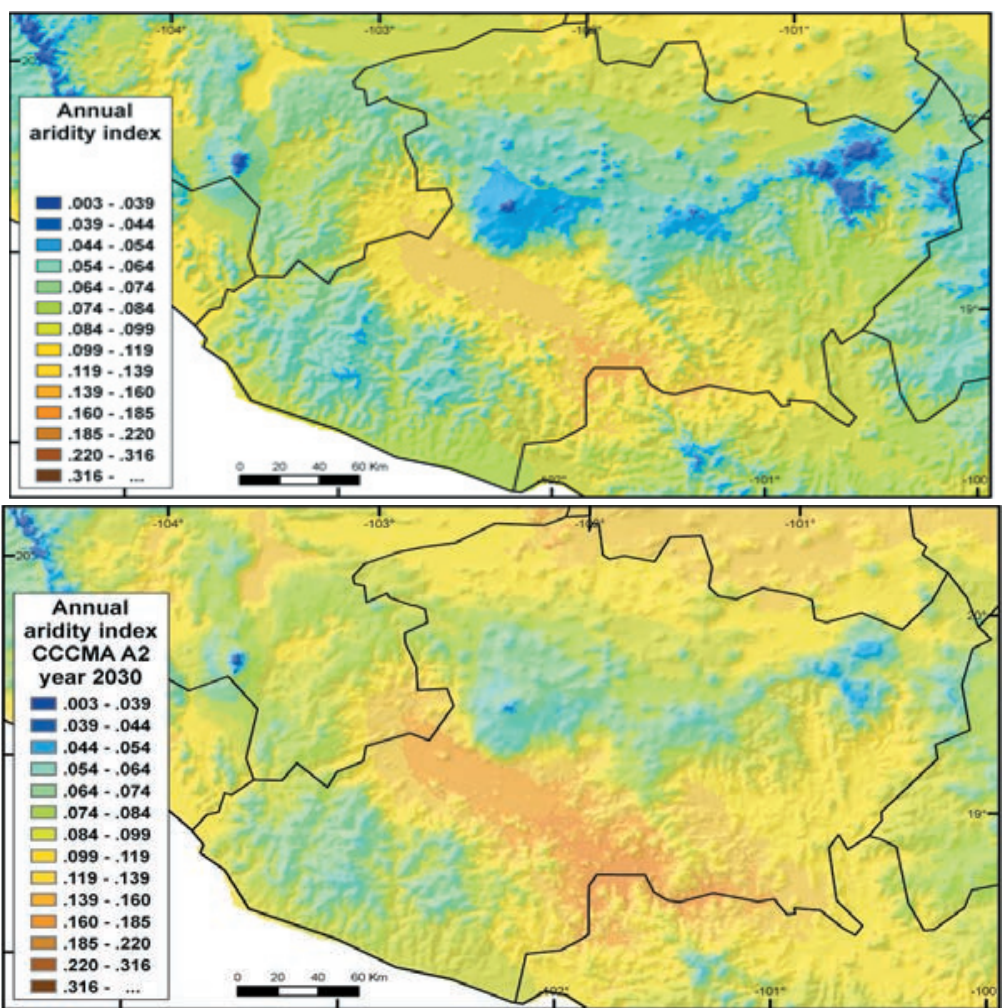

(c)

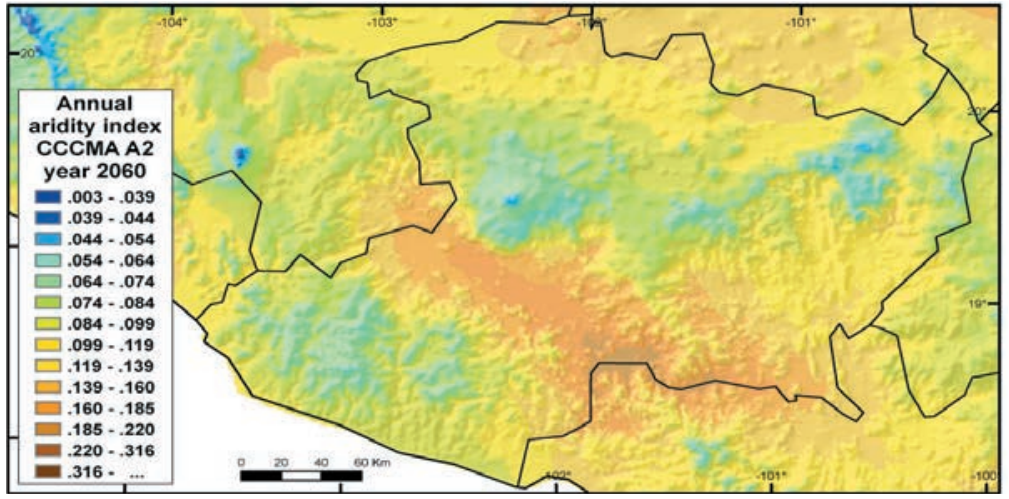

(d)

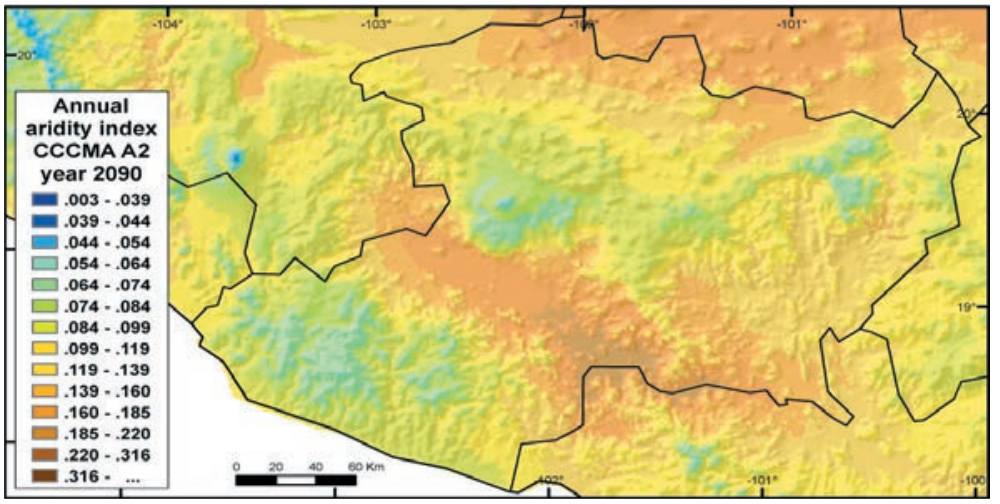

Figure 8. Annual aridity index (degree days $>5^{\circ} \mathrm{C}$ divided by precipitation) for contemporary (a), 2030 decade (b), 2060 (c) 2090 (d) climates, using output from the Canadian Center for Climate Modeling and Analysis model scenario A2. 
and to higher elevations (Rehfeldt et al., 1999; Tchebakova et al., 2005; Hamann and Wang, 2006; Rehfeldt et al., 2006; Wang et al., 2006). However, the expectation for México, given the complex climate, geography and the large semiarid region of the North Central Plateau, is that general migration of vegetation would be toward higher elevations rather than in a northerly direction (Sáenz-Romero et al., 2010).

In Michoacán State, the northern semiarid region (on the border with Guanajuato State, brownish colors in Figure $8 \mathrm{~d})$ will likely act as a barrier against plant species migration northwards. The likely direction of migration, if any, is toward higher altitudes along the slopes of the mountains in the Neovolcanic Axis and of the Sierra Madre del Sur. The expansion of the semiarid climate from north to south from the Guanajuato border, and to the northwestern and southeast along the valley of the Balsas Depression (Figures $8 \mathrm{~b}$ to $8 \mathrm{~d}$ ), will probably favor the expansion of xeric bush and grasslands vegetation communities. The former will possibly invade areas presently occupied by tropical dry forest, while the latter will likely occupy areas covered with oak and pine-oak vegetation.

It must be remarked, that the speed of natural migration will unlikely match the speed of the migration needed to match genotypes with environments. For example, the accumulated increase of annual average temperature, estimated between 0.6 and $0.9^{\circ} \mathrm{C}$ (depending on the place), occurred in France due to climate change in the 20th century. This increment, apparently, has caused an average shift upwards of $65 \mathrm{~m}$ of the optimal altitudinal distribution of several plant species. The shift was estimated for a period of 22 years (1971 to 1993). This means a natural migration rate of $29.6 \mathrm{~m}$ upwards per decade (Lenoir et al., 2008).

However, estimations of the increase in altitudinal distribution predicted for populations of Pinus pseudostrobus and $P$. hartwegii distributed in Michoacán State, indicate that to match adaptation from contemporary climate to the projected climate (Canadian Model, scenario A2) for the 2030 decade, will require an altitudinal shift upwards of 400 to $450 \mathrm{~m}$ (Figure 9); a migration rate between $191 \mathrm{~m}$ and $214 \mathrm{~m}$ per decade ( 6.5 to 7.2 times faster than the rate observed in France). This shift assumes that populations have not shifted upwards already, that this migration is needed for the period 2009 to 2030 at Michoacán, and that the annual aridity index (AAI) is a good climate predictor for those species. If the climate match is extended to the 2060 decade, the altitudinal shift required is between 600 to 800 $\mathrm{m}$ (Figure 9). Pinus hartwegii populations currently at 3500 $\mathrm{m}$ of altitude or more do not have a place to move since the highest mountain in Michoacán State is Pico de Tancítaro with $3800 \mathrm{~m}$ of altitude, thus lower altitudinal populations of $P$. hartwegii would need to be replaced by P. pseudostrobus populations (Figure 9).

This estimation highlights a need to implement an assisted migration program, as the one suggested by Tchebakova et al. (2005). This program consists of massive planting with seed collected from current populations, and nurseryproduced seedlings to be planted in locations where their adaptation climate will occur by year 2030 or so. Undoubtedly, this will imply numerous risks and challenges, due to unexpected negative interactions with current species occupying the targeted planting sites, unsuitable soils and many other factors (van Zonneveld et al., 2009).

However, there is no choice since climate change will force tree species to adapt, to migrate or to disappear (Davis, 1989; Rehfeldt et al., 2001; Davis et al., 2005; Aitken et al., 2008). Considering that phenotypic plasticity could be exhausted (Saxe et al., 2001), the natural migration at the required speed seems unlikely; the present suitable habitats for pines will be reduced by up to $64 \%$ and for oaks by 7 to $48 \%$ by 2050 in México, depending of the climate scenario used for estimating effects (Gomez-Mendoza and Arriaga, 2007). No management actions seem a bad option (McLachlan et al., 2007), and assisted migration is perhaps an inescapable management option, even with its implied risks.

The increasing expected stress for wild plants due to climate change will be applied also to domesticated commercial crops. Crop production will most certainly be affected, particularly in areas depending on the rainy season, which is expected to decrease in intensity (see Figure 2). A $5 \%$ to $30 \%$ decrease in cereal yield is forecasted for México by 2080 (Parry et al., 2004).

\section{CONCLUSIONS}

Contemporary climate for Michoacán State has a mean annual temperature of $20.3^{\circ} \mathrm{C}$ and a mean annual precipitation of $909 \mathrm{~mm}$. Predicted future climate (averaging outputs from three general circulation models and two emission scenarios (A2 and $\mathrm{B}$ ) indicates a temperature increase of $1.4^{\circ} \mathrm{C}$ in the decade centered in year 2030 , of $2.2^{\circ} \mathrm{C}$ by 2060 , and of $3.6^{\circ} \mathrm{C}$ by 2090 . Annual precipitation is predicted to decrease by $5.6 \%$ by $2030,5.9 \%$ by 2060 , and $7.8 \%$ by 2090 . Precipitation decrease could be as large as $24.2 \%$, as predicted by the Canadian Model, emission scenario A2.

Estimates and spline climate models available at http://forest.moscowfsl.wsu.edu/ climate/ can be used as resources to plan assisted migration of forest tree species to minimize projected impacts of climate change and for conservation programs. 


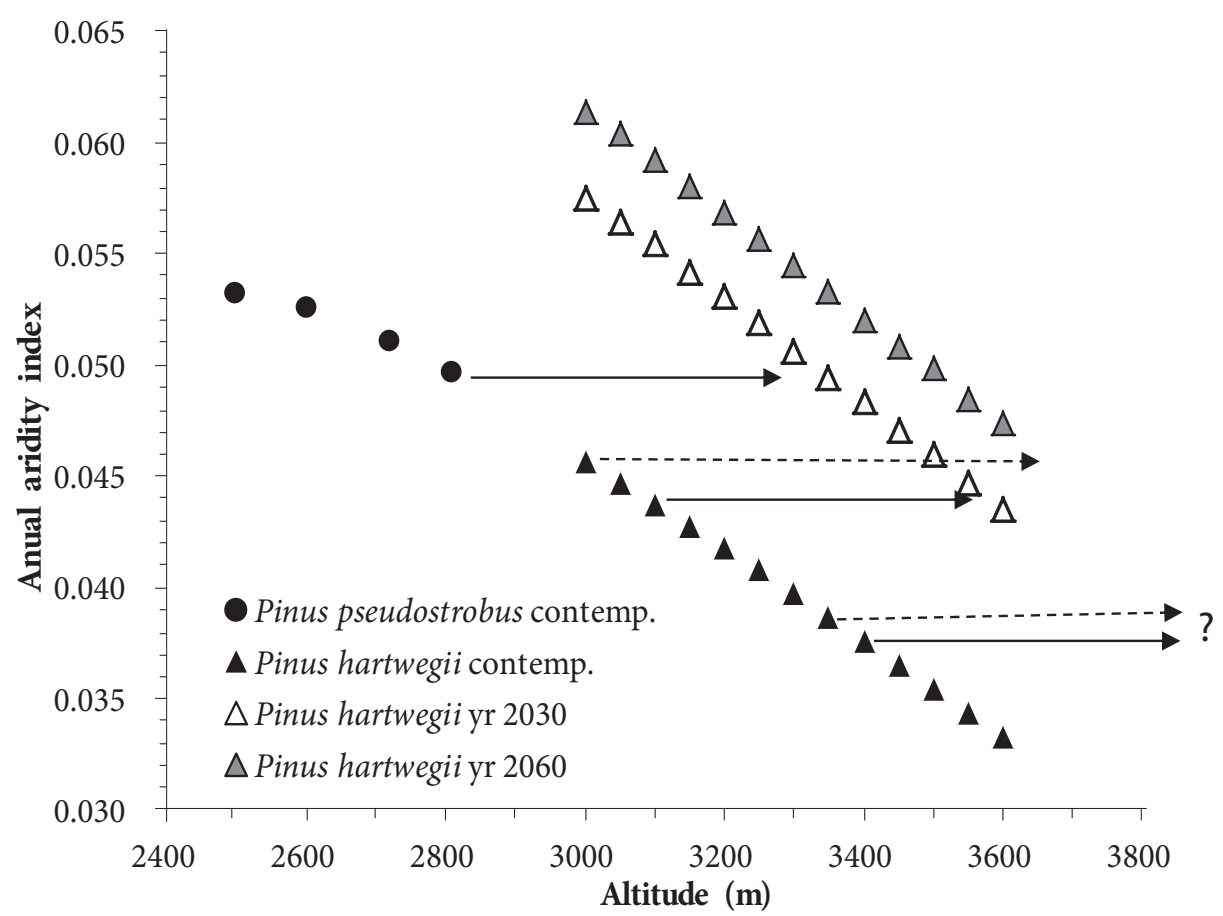

Figure 9. Annual aridity index estimated for locations presently inhabited by Pinus hartwegii and P. pseudostrobus in Michoacán State, for contemporary (filled symbols) and future climates (2030 decade empty symbols, 2060 decade gray symbols, Canadian model scenario A2; future climate only for $P$. hartwegii). Arrows suggest assisted migration to higher altitude to match current genotypes with locations where adaptation matches annual aridity; 2030 decade, solid arrows; 2060 broken arrows.

\section{ACKNOWLEDGEMENTS}

Part of this research was conducted during a sabbatical year of CSR at the Centre Canadien sur la fibre de bois, Service Canadien des Forêts, Ressources Naturelles Canada, Québec. Financial support for the sabbatical was provided by Natural Resources Canada, Mexican Council of Science and Technology (CONACYT, scholarship 75831), Universidad Michoacana de San Nicolás de Hidalgo (UMSNH), and research grants by a joint research fund between CONACYT and the state of Michoacán (Fondo Mixto CONACyT-Michoacán, project 2009-127128) and by Coordinación de la Investigación Científica, UMSNH. Three anonymous reviewers and one writing style reviewer helped to improve significantly the manuscript.

\section{BIBLIOGRAPHY}

Aitken S N, S Yeaman, J A Holliday, T Wang, S Curtis-McLane (2008) Adaptation, migration or extirpation: climate change outcomes for tree populations. Evol. Appl. 1:95-111.

Brown J H, A C Gibson (1983) Biogeography. CVMosby, St. Louis, Missouri. $643 \mathrm{p}$.

Christensen J H, B Hewiston, A Busuioc, A Chen, X Gao, I Held, R Jones, R K Kolli, W T Kwon, R Laprise, V Magaña Rueda, L Mearns, C G Menéndez, J Räisänen, A Rinke, A Sarr, P Whetton (2007) Regional climate projections. In: Climate Change 2007: The Physical Science Basis; Contribution of Working Group I to the Forth Assessment Report of the In- tergovernmental Panel on Climate Change. S Solomon, D Qin, M Manning, Z Chen, M Marquis, K B Averyt, M Tignor, H L Miller (eds). Cambridge University Press. Cambridge, UK and New York, NY. pp: 847-940.

Comisión Forestal del Estado de Michoacán, COFOM (2001) Atlas Forestal del Estado de Michoacán. COFOM. Morelia, Michoacán, México. $97 \mathrm{p}$.

Cué-Bär E M, J L Villaseñor, L Arredondo-Amezcua, G Cornejo-Tenorio, G Ibarra-Manríquez (2006) La flora arbórea de Michoacán, México. Bol. Soc. Bot. Méx. 78:47-81.

Davis M B (1989) Lags in vegetation response to greenhouse warming. Climate Change 15:75-82.

Davis M B, R G Shaw, J R Etterson (2005) Evolutionary responses to changing climate. Ecology 86:1704-1714.

Globe Task Team (1999) The Global Land One-kilometer Base elevation (GLOBE) Digital Elevation Model, version 1.0. National Oceanic and Atmospheric Administration, National Geophysical Data Center, Boulder, Colorado.

Gomez-Mendoza L, L Arriaga (2007) Modeling the effect of climate change on the distribution of oak and pine species of México. Conserv. Biol. 21:1545-1555.

Hamann A, T Wang (2006) Potential effects of climate change on ecosystem and tree species distribution in British Columbia. Ecology 87:2773-2786.

Hughes L (2000) Biological consequences of global warming: is the signal already. Trends Ecol. Evol. 15:56-61.

Hutchinson M F (2004) ANUSPLIN version 4.3 user guide. Centre for Resource and Environmental Studies, Australian National University. Canberra, Australia. 54 p.

Intergovernmental Panel on Climate Change, IPCC (2000) Emissions Scenarios; Summary for Policymakers. Special Report of IPCCC Working Group III. IPCC. USA. 21 p. Available at: http://www.ipcc.ch/pdf/special-reports/spm/sres-en.pdf. （visited May 2008). 
Ledig F T, J H Kitzmiller (1992) Genetic strategies for reforestation in the face of global climate change. For. Ecol. Manage. 50:153-169.

Ledig F T, G E Rehfeldt, C Sáenz-Romero, C Flores-López (2010) Projections of suitable habitat for rare species under global warming scenarios. Amer. J. Bot. 97:970-987.

Lenoir J, J C Gégout, P A Marquet, P de Ruffray, H Brisse (2008) A significant upward shift in plant species optimum elevation during the 20th Century. Science 320:1768-1770.

McLachlan J, J J Hellmann, M W Schwartz (2007) A framework for debate of assisted migration in an era of climate change. Conserv. Biol. 21:297-302.

Minami M (2000) Using ArcMap; GIS by ESRI. Environmental Systems Research Institute (ESRI), Redlands, California.

Parry M L, C Rosenzweig, A Iglesias, M Livermore, G Fisher (2004) Effects of climate change on global food production under SRES emissions and socio-economic scenarios. Global Environ. Change 14:53-67.

Pavia E G, F Graef , J Reyes (2009) Annual and seasonal surface air temperature trends in Mexico. Int. J. Climat. 29:1324-1329.

Rehfeldt G E, C C Ying, D L Spittlehouse, D A Jr Hamilton (1999) Genetic responses to climate in Pinus contorta: niche breadth, climate change, and reforestation. Ecol. Monographs 69: 375-407.

Rehfeldt G E, R A Wykoff, C C Ying (2001) Physiologic plasticity, evolution, and impacts of a changing climate in Pinus contorta. Climate Change 50:355-376.

Rehfeldt G E (2006) A spline model of climate for the western United States. Gen.Tech. Rep. RMRS-GTR-165, Fort Collins, Colorado, USDA Forest Service. 21 p.

Rehfeldt G E, N L Crookston, M V Warwell, J S Evans (2006) Empirical analyses of plant-climate relationship for the western United States. Int. J. Plant Sci. 167:1123-1150.

Rzedowski J (1978) Vegetación de México. Ed. Limusa, México. 432 p.

Sáenz-Romero C (2005) El patrimonio forestal de Michoacán y su problemática. In: La Biodiversidad en Michoacán. Estudio de Estado. CONABIO - Secretaría de Urbanismo y Medio Ambiente (SUMA), Gobierno del Estado de Michoacán - UMSNH. Morelia, Michoacán, México. pp:128-129.

Sáenz-Romero C, R Guzmán-Reyna, G E Rehfeldt (2006) Altitudinal genetic variation among Pinus oocarpa populations in $\mathrm{Mi}$ choacán, México; implications for seed zoning, conservation of forest genetic resources, tree breeding and global warming. For. Ecol. Manage. 229:340-350.
Sáenz-Romero C, G E Rehfeldt, N L Crookston, P Duval, R St-Amant, J Beaulieu, B A Richardson (2010) Spline models of contemporary, 2030, 2060 and 2090 climates for Mexico and their use in understanding climate-change impacts on the vegetation. Climatic Change 102:595-623.

SAS Institute (1998) SAS/STAT Guide for personal computers, version 8.0. SAS Institute, Cary, North Carolina.

Saxe H, M G R Cannell, Ø Johnsen, M G Ryan, G Vourlitis (2001) Tree and forest functioning in response to global warming. New Phytol. 149:369-399.

St Clair J D, G T Howe (2007) Genetic maladaptation of coastal Douglasfir seedlings to future climates. Global Change Biol. 13:14411454 .

Tchebakova N M, G E Rehfeldt, E I Parfenova (2005) Impacts of climate change on the distribution of Larix spp. and Pinus sylvestris and their climatypes in Siberia. Mitig. Adapt. Strat. Global Change 11:861-882.

Téllez-Valdés O, P Dávila-Aranda (2003) Protected areas and climate change: a case study of the cacti in the Tehuacán-Cuicatlán biosphere reserve, México. Conserv. Biol. 17:846-853.

Tukanen S (1980) Climatic parameters and indices in plant geography. Acta Phytogeog. Sue. 67:1-105,

van Zonneveld M, A Jarvis, W Dvorak, G Lema, C Leibing (2009) Climate change impact predictions on Pinus patula and Pinus tecunumanii populations in Mexico and Central America. For. Ecol. Manage.t 257:1566-1576.

Villaseñor-Gómez L E (ed) (2005) La Biodiversidad en Michoacán: Estudio de Estado. Comisión Nacional para el Uso de la Biodiversi dad, Secretaría de Urbanismo y Medio Ambiente, Universidad Michoacana de San Nicolás de Hidalgo. México. 266 p.

Viveros-Viveros H, C Sáenz-Romero, J López-Upton, J J Vargas-Hernández (2005) Altitudinal genetic variation in plant growth of Pinus pseudostrobus Lindl. in field testing. Agrociencia 39:575587.

Viveros-Viveros H, C Sáenz-Romero, J J Vargas-Hernández, J LópezUpton, G Ramírez-Valverde, A Santacruz-Varela ( 2009) Altitudinal genetic variation in Pinus hartwegii Lindl. I : Height growth, shoot phenology, and frost damage in seedlings. For Ecol. Manage. 257:836-842.

Wang T, A Hamann, A Yanchuk, G A O ' Neill, S N Aitken (2006) Use of response functions in selecting lodgepole pine populations for future climates. Global Change Biol. 12:2404-2416.

Woodward F I (1987) Climate and plant distribution. Cambridge University Press, London. $174 \mathrm{p}$. 